\title{
THE USE OF FOREIGN FORMS TO CIRCUMVENT LOCAL LIABILITY RULES
}

\author{
ROBERT FLANNIGAN*
}

Liability assignments for wrongs committed within a jurisdiction are generally intended wo apply equally fo all local and foreign persoms. Local fiability policy. however, con be cincumented through the 1 se of foreign legal forms. Both local and forcign persons may reduce their liability exposure by conducting their activities in the local jurisdiction through a foreign form that has becn endowed by its jurisdiction of origin with a wider limitation of liabilin: The differences in liability exposure are often significant. They appear to be folerated or ambraced because they. serve local commercial, professional. and governmentat interests. Uthimaty. the costs of the resulfam elevated risk of loss are bone by locat rexidenis.
La deferminution de la responsabilike pour les ramsgressions commises dans whe juridiction doit

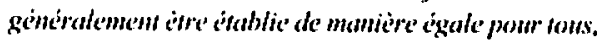

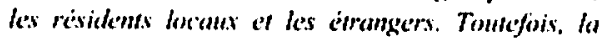
politique de la responsubilite hocale pent itro combonme en utilisom des formulaires juridiques itrangers. Les résidents locaux et les itrangers pewien reidure feur exposition en effectum leurs activites dans la juridiction locale au molen diun formulaire e'tranger domé par la juridiction d'origine 'l ạam whe plus grande limite de responsabilik'. Les differcences deryposition a la responsabilite som somen considirables. Elles semblent tolire'es on odophe's paser qu'elles servens les imfiriss

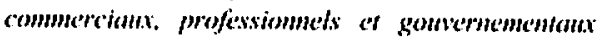

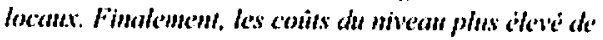
risque de perte qui en résuhe reposent sur les risidk'ms locum.

\section{TABLE OF CONTENTS}

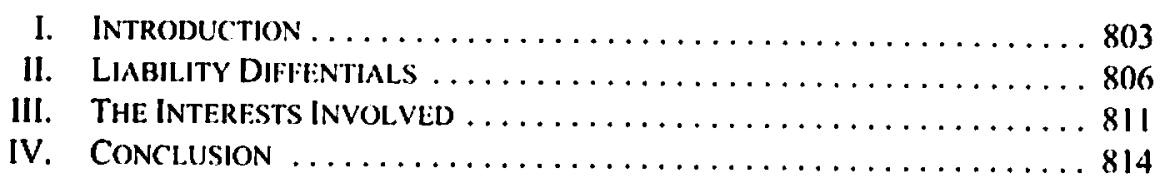

\section{INTRODUCTION}

Many jurisdictions allow foreign organization forms (e.g. corporations, partnerships, trusts) to pursue commercial or non-profit activities within their boundaries. Often the local jurisdiction will recognize certain of the foreign legal incidents of the foreign forms, thereby leaving various issues to be resolved for local purposes by the law of the foreign jurisdiction. That local recognition of the law of origin is typically generalized and does not involve specific assessment of the foreign/local differences in individual cases. That obviously produces exploitable opportunities for those who wish to avoid the application of inconvenient local rules. It allows either local or foreign persons to establish foreign structures to carry on undertakings locally that will not be subject to the same legal discipline applied to local forms. The public policy reflected in the laws of the local jurisdiction can thus be circumvented simply by form selection. That prospect apparently has raised little concern in local legislatures. Possibly there is a failure to understand the nature and magnitude of the differences that currently exist between jurisdictions. Or perhaps pragmatic incentives operate to maintain those differences. In what follows, I will review a number of exploitable liability differences. 1 conclude. pessimistically, that there is only a remote 
prospect that individual jurisdictions will act to protect their own citizens from the liability consequences of rote form recognition.

The applicable conflict rules are variable or vague in different respects across legal forms and jurisdictions.' It seems, however, that most jurisdictions do subscribe to the view that the validity of the creation or existence of a foreign structure is determined by the law of the jurisdiction of origin. Many jurisdictions also accept that the internal affairs of a foreign organization should be governed by the law of origin. There is, however, a lack of clarity as to what is contemplated by the notion of "internal affairs."2 Specifically, it is unclear whether limitations of liability are to be treated as internal matters. On the face of it, an immunization against third party liability would seem to be outside any conception of internal affairs. Judicial and other views, however, are incomplete or unsatisfactory. The American Law Institute's Restatement suggests that, notwithstanding decisions of the United States Supreme Court imposing local liability rules on foreign shareholders, ${ }^{3}$ the American position is uncertain or contingent. ${ }^{4}$ In England, a weak line of authority provides unsure support for the

For early commentary on the liability question in the corporate context, see the notes at (1904-1905) 18 Han. L. Rev. 452; (1905) 5 Colum. L. Rev. 231; (1905) 21 Law Q. Rev. 105; (1906) 22 Law Q. Rev. 122; (1905) 5 Colum. L. Rev. 606; (1906) 6 Colum. L. Rev. 45; (1916-1917) 26 Yale L.J. 143; (191718) 27 Yale L.J. 248. See also Wesley New comb Hohfeld, "Nature of Stockholders' Individual Liability For Corporation Debts" (1909) 9 Colum. L. Rev. 285 and "The Individual Liability of Stockholders and the Conflict of Laws" (1909) 9 Colum. L. Rev. 492 (continued at (1910) 10 Colum. L. Rev. 283 and 520). For modern commentaries on the various forms, see Brad A. Milne, "Exıra-Provincial Liability of the Limited Parner" (1985) 23 Alta. L. Rev. 345; Thomas E. Rutledge. "To Boldly Go Where You Have Not Been Told You May Go: LLCs, LLPs, and LLLPs in Interstate Transactions" (2006) 58 Baylor I.. Rev. 205.

2 On concerus with the inlernal allairs notion, and with the recognition of foreign fonms generally, see the notes at (1933) 33 Colum. L.. Rev. 492; (1946) 46 Colum. L. Rev. 413; (1932-33) 31 Micl. L. Rev. 682; 11960] Duke L.J. 477; (20102) IIS Ilarv. L. Rev. 1480. See also Elvin R. Latty, "Pscudo-Fortign Corporations" ( 1955 ) 65 Yalc L.J. 137: Stanley A. Kaplan, "Foreign Corporations and Local Corporate Policy" (1968) 21 Vand. I. Rev. 433; J. Thomas Oldham, "California Regulates Pscudo-Foreign Coporations - Trampling Upon the Tramp?" (1977) 17 Santa Clara L. Rev. 85; P. John Kozyris, "Corporate Wars and Choice of Law" [1985] Duke L.J. 1; Deborah A. DeMott, "Perspectives on Choice of Law For Corporate Internal Aflairs" (1985) 48:3 Law \& Contemp. Probs. 161; Richard M. Buxbaum, "The Threatened Constitutionalization of the Internal Affairs Doctrine in Corporation Law" (1987) 75 Cal. L. Rev. 29: Lamy E. Ribstein. "From Efficiency to Politics in Contractual Choice of Law" (2003) 37 Ga. L. Rev. 363; Frederick Tung. "Before Competition: Origins of the Intemal Affairs Doctrine" (2006) 32 J. Corp. 1. 3.3.

3 Pinney v. Nelsom, 183 U.S. 144 (1901): Thomas v. Mathiessen, 232 U.S. 221 (1914).

- The American Law Institute, Resforement of the Law. Second: Conflict of Laws 2d, vol. 2 (St. Paul, Minn.: American Law Institute Publishers, 1971) $\$ 307$ [Restatemen/], states that: "The local law of the state of incorporation will be applied to determine the existence and extent of a shareholder's liability to the corporation for assessments or contributions and to its creditors for corporate debts." See Mark R. Patterson, "Is Unlimiled L.iability Really Unattainable?; Of Long Ams and Short Sales" (1995) 56 Ohio St. L.J. 815 at $862-68$, who insists that $\$ 307$ does not deal with liability after initial capitalization and that, instead, the matter is a question of most significant relationship under $\$ 302$. That it is an issue of "most signiticant relationship" may actually be the de facto position under $\$ 307$ because, under its Reporter's Note, the Suprenc Court cases cited ibid. are said to justify imposing the local liability "if the state's relationship to the shareholder is sufficient to make reasonable the imposition of such liability upon him." A part from that, in terms of rationale, the comment $10 \$ 307$ claims that the law of origin will be applied "because (1) this is the law which shareholders, to the extent that they thought about the question, would usually expect to have applied to delermine their liability, (2) exclusive application of this law will assure uniform treatment of shareholders or of classes of shareholders and (3) this state will usually have the dominant interest in the determination of this issue." In response, it may be observed that ( 1 ) it is rather more plausible that shareholders assume, because it is the case in other respects, that 
view that liability is determined by the jurisdiction of origin.' Other commentators probe more deeply, but invariably without resolution." Generally it seems that the definitive analysis remains to be undertaken. As it is, the default position is not of exclusive or even primary significance for this inquiry. That is because most jurisdictions of present interest have explicitly addressed the possible liability differentials of forcign forms (often disjunctively referring to both internal affairs and limited liability) and. therefore, do not depend on the default position. ${ }^{7}$ Of those, several have formally recognized, in mechanical fashion, the application of foreign liability policy. The question is why they would do so, a question that is not limited to cases where the selection of the foreign form is primarily for the purpose of liability circumvention by local residents.

A common rationale for recognizing the internal law of foreign structures, whether by default or express legislative choice, is interjurisdictional comity. ${ }^{8}$ That vague rationale is typically asserted, rather than developed, and it is doubtful that it amounts to a sufficient justification for exposing local populations to the increased level of risk associated with

they are subject to the liability rules of the jurisdictions where the undertaking operates (Query. moreover, why sharcholder expectation should trump either local law or third party injury.). (2) the direct consequence is that there will be no uniformity between the shareholders of local and foreign corporations pursuing undertakings in the local jurisdiction and (3) the lecal jurisdietion clearly has the dominant interest in its duty 10 protect its population against risk and injury.

3 The English position appears to be largely dependiant on une undeveloped assertion in a leading text. In Mockaine Wasson \& Co. Lrd. v. Deparmem of Trade and hrdestry. [1989] i Ch. 72 at 178 (C.A.). Kerr L.J. referred to the statement in the Il thedition of Dicev and .Morris (sec Lawrence Collins, ed. Dicey and Morris on the Conflict of Lai's, 11 th ed., vol. 2 (London: Stevens \& Sons, 1987) at 1134) that the law of the place of incorporation governs "the extent of an individual member's liability for the debts or engagements of the corporation." As Kerr L.J. saw it: "While the authority cited is seanty, the text rightly submits that "the rule is soundly based in that reference to any other legal system would be absurd." That hardly amounts to a satisfactory analysis given the observation of scanty authority. The same may be said of the comment of Lord Oliver on the subsequent appeal to the House of Lords ([1990] 2 A.C. 418 (H.L.) at 509). According to him: "The athorities cited in Dicel \& Morris ... for the starting proposition on which the argument is founded are, as Kerr L.J. remarked, somewhat exiguous but the proposition is, I think. a legical one and can be accepled. At any rate, lor present purposes, it can be assumed to be correct." The rule, however, is not inevitable or inescapable - it is a policy choice - and the courts should investigale (not assume) that choicc. Later cases add nothing in terms of justification for the rule. Consider the authorities now cited in the current edition of Lawrence Collins, ed., Dicey. Morris and Collins on the Conflict of l.aws, 14th ed., vol. 2 (London: Sweet \& Maxwell, 2006) at 30-024.

- See the materials in supro note 2. Patterson, supro note 4 at 862-68, regards the matter as a policy contest between tort and corporale law. The only conlest, however, is between different corporation laws in an essentially uniform tort law environment. It is an aspect of corporale law to direct that shareholders of foreign corporations shall be subject to the same liability laws that govern shareholders of lecal corporations.

They are clearly free in most respects 10 impose whatever conditions they wish on forcign forms

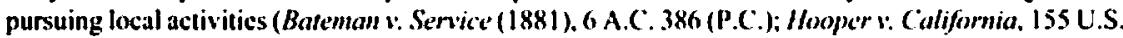
$648(1895)$ ), though few seek to override forcign limited liability. Sec, for example, the Alberta and Saskatchewan limited partnership provisions, infira note 31.

* Consider King v. Sarria, 69 N.Y. 24, 25 Am. Rep. 128 (1877); Empire Wills v. Alsson Grocery Co., 15 S.W. 505 (Tex. App. 1891). 
increased immunity. ${ }^{9}$ A second supposed rationale is the economic benefit of free trade. ${ }^{10}$ That too is a weak or unsatisfactory justification. Both of these rationales, in their strongest form, are premised on a general correspondence, or the absence of fundamental conflict, between local and foreign laws. Virtually every description of the recognition rule, for example, is qualified by the caveat that foreign law will not apply where it diverges from the public policy of the local jurisdiction." Also, in the case of the free trade argument, the implicit assumption is that local trade is conducted by actors in essentially cquivalent liability (i.e., accountability) positions relative to the community. That is, no traders have significant advantages conferred on them by the jurisdiction of origin of their legal form.

\section{LiABILITY DifFERENTIALS}

Perhaps the most familiar example of jurisdiction shopping is that in the United States, where individual states produce their own corporation laws. ${ }^{12}$ From the beginning of the twentieth century, according to the standard account, states competed with each other for incorporations with a view to raising revenues for themselves and, coincidentally, their local bars. New Jersey prevailed initially" but was ultimately displaced by Delaware in the race to the bottom/top. ${ }^{\text {th }}$ Delaware became the locale of choice because, depending on one's view of the race, it was most responsive to the needs of managers or investors. The competition was generally not over basic contract and tort liability, where there was broad uniformity. Rather, so the tale goes, it was about managerial discretion and appropriate constraints on that discretion.

On the problemalic character of the comity principle, see generally Louise Weinberg. "Against Comity" (1991)80 Gco. L.J. 53; Michacl D. Ramscy, "Escaping 'Intemational Comity"” (1998) 83 lowa L. Rev. 893. Ste also the note at (2002) 115 I Jarv. L. Rev. 1480. On limited liability partnerships, see Robert R. Keatinge et al., "The Limiled Liability Company: A Study of the Emerging Entity" (1992) 47 Bus. Law. 375 at $453-54$. Typically as a constitutional argument in support of interjurisdictional commerce in federal states.

"S See, e.g., Canadian Pacific Ruiluay Co. v. Western Union Telegraph Co. (1889), 17 S.C.R. 151 at 155:

The comity of nations distinctly recognises the right of foreign incorporated companies to carry on business and make contracts outside of the country in which they are incorporaled, if consistent with the purposes of the corporation, and not prohibited by its charter, and not inconsistent with the local laws of the country in which the business was carried on, subject always to the restrictions and burthens imposed by the laws enfored therein; for there can be no doubt that a state may prohibit forcign corporations from transacting any business whatever, or it may permil them to do so upon sucli proper terms and conditions as it may preseribe.

As in Canada, the American federal government may also create corporations. Additionally, it has regularly intervened to displace lax state corporate law with tighter regulation. See Lucian A. Bebchuk \& Assar Hamdani, "Federal Corporate Law: Lessons From Ilistory" (2006) 106 Colum. L. Rev. 1793. See Edward Q. Keasbey. "New Jersey and the Great Corporations" (1899-1900) 13 Harv. L. Rev. 198; Lincoln Steffens, "New Jersty: A Traitor State (Part II)" (1905) 25 McClure's Magazinc 4l; Harold W. Stoke, "Economic Influences Upon the Corporation Laws of New Jersey" (1930) $38 \mathrm{~J}$. Pol. Econ. 551; Christopher Grandy, "New Jersey Corporale Chantermongering, 1875-1929" (1989) 49 J. Econ. Hist. 677.

14 See Marcel Kahan \& Ehud Kamar, "The Myth of State Competition in Corporale Law" (2002) 55 Stan. L. Rev. 679; Lucian Arye Behchuk \& Alma Cohen. "Firms' Decisions Where to Incorporate" (2003) 46 J.L. \& Econ. 383; Jens C. Dammann, "Freedom of Choice in European Corporate Law" (2004) 29 Yale J. Int'I L. 477; Guhan Subramanian, "The Disappearing Delaware Elfecl" (2004) 20 J.L. Econ. \& Org. 32; Daniel J.H. Greenwood, "Democracy and Delasware: "The Mysterious Race to the Bottom/Top" (2005) 23 Yale L. Pol'y Rev. 381; Robert Drury, "The 'Delaware Syndrome': turopean Fears and Reactions" [2005] J.B.L. 709; Seth Chertok, "Jurisdictional Competition in the European Community" (2006) 27 U. Pa. J. Int'I Econ. L. 465. 
There was one major jurisdiction where liability exposure was a significant consideration well into the twentieth century. California corporate law provided for proportionate liability for the shareholders of local corporations. ${ }^{15}$ That was a concern for foreign corporations because the constitution of Califormia declared that the shareholders of foreign corporations were not to receive preferential treatment: "No corporation organized outside the limits of this State shall be allowed to transact business within this Statc on more favourable terms than are prescribed by law to similar corporations organized under the laws of this State."16 The liability diflerence between California and other stales persisted for decades without any apparent adverse effects on California. ${ }^{17}$ Ultimately, however, unlimited liability was eliminated in 1931 and California accepted the now essentially universal standard of liability restricted to the subscription amount. ${ }^{\text {is }}$

In the latter decades of the twentieth century, competition turned to the creation of new legal forms, notably the limited liability company, the limited liability partnership, and the statutory business trust. ${ }^{19}$ These new forms were directly concerned with reducing the liability exposure associated with conventional partnerships and trusts. The limited liability company combined limited liability with flow through taxation. the limited liability partnership eliminated the vicarious liability of general partners, and the statutory business trust discarded the control test of beneficiary liability. The prospect harboured by some states of becoming the new Delaware for these forms, however, was substantially diminished when other states quickly followed the first movers and passed legislation to defend their market share of business formations. ${ }^{20}$. While substantial differences amongst the various jurisdictions remain, the American uniform law commissioners are drafting model statutes designed to achicve a measure of uniformity for these forms. ${ }^{31}$

In Canada, in the corporate context, provincial jurisdiction shopping appears to be less common. ${ }^{22}$ To the extent that it occurs now, it is rarely based on shareholder liability exposure, as virtually every Canadian jurisdiction has comparable general limited liability

1s See Palterson. supra note 4 at 820-23.

is Cal. Const, art. XII. \$ 15 (1870) (repealed 1972). Now, since 1976, see Cal. Corp. Code $\$ 2115$. applying California law to certain aspects of the internal aflairs of forcign corporations.

17. California and New York are execptions in that they have persisled in requiring forcign forms to comply with their leceal corporate policy in various malters of internal aflairs. See DeMoth, stymer noke 2. Their ability to do so is usually attributed to their ceonomic dominance.

is California?s attempts to impose local policy on forcign firms have been thwaned by courts of foreign jurisdictions when litigation was commenced in those courts. Sce Risdon Iron amd locomotive Works i. Furness. [1906] I K.B. 49 (C.A.); Vamagepoint Vemure l'armers 1996 v. Examen Inc., 871 A.2d 1108 (DAl. 2005).

19 See Rubert Flannigan, "The Political Path to Limited Liability in Business Trusts"(20106) 31 Advocates" Q. 257, online: Social Science Research Network <htup://ssrn.com/abstract=89560)>.

30 $\quad$ hid.

21 Jbid. Given the interests involved, query the influence that unilorm legislation does or should have. See Larry E. Ribsicin \& Bruce H. Kohayashi, "An Economic Analysis of Uniform State Laws" (1996) 25 J. Legal Stud. 1.31.

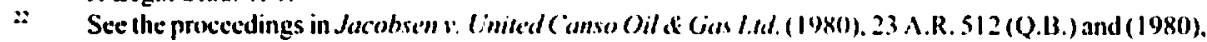
40 N.S.R. (2d) 692 (S.C. (T.D.)), where a federal company continued into Nova Scotial secking a more favourable legislative foundation lor its voting cap. Comsider also Douglas J. Cuming \& Jeflerey G. Macintosh. "The Role of Interjurisdictional Competition in Shaping Canadian Corporale Law" (2000) 20 Int'l Rev. L. \& Econ. 141 and "The Rationales Underlying Reincorporations and Implications For Canadian Corporations" (2002) 22 Int'I Rev. L. \& Econ. 277. 
for contract and tort losses. ${ }^{23}$ The real concern, going forward, is with the other structures that may be employed to carry on commercial or non-profit undertakings. Currently there are significant liability differences between jurisdictions that may be sufficiently attractive to drive the decision where to originally establish the legal form and, thereby, effectively circumvent local liability policy. Here I will canvass a number of possibilities for attenuating liability through the use of limited partnerships, limited liability partnerships, trusts, and nonprofit corporations. I make no attempt to comprehensively catalogue all of the various possibilities.

In the case of the limited partnership, the liability of limited partners in most Canadian jurisdictions has long depended on whether the limited partners participate in the control of the business. Since 1965, there has been one notable exception to this control test. In Manitoba, ${ }^{24}$ a limited partner who "takes an active part in the business of the partnership" is only liable as a general partner "to any person with whom he deals on behalf of the partnership and who does not know he is a limited partner for all debts of the partnership." 25 That provision reduces liability exposure relative to other Canadian jurisdictions by requiring that a limited partner (1) actually deal with the third party and (2) that the third party not know of the limited partner status. The resultant reduced exposure has been duly noted by the bar, ${ }^{26}$ and Manitoba limited partnerships have been utilized across the country for undertakings and transactions that have no real economic connection with Manitoba. ${ }^{27}$

A more significant difference in liability exposure exists between limited partnerships organized in certain Canadian provinces and limited partnerships organized in states that have adopted the most recent version of the American uniform statute. ${ }^{28}$ The American uniform legislation eliminates the control test entircly, allowing limited partners to freely

-3 Unlimited liability is the tax driven objective for some form selections. For many years, Nova Scotia was the only Canadian jurisdiction to offer a corporate structure with a form of default open liability (which allowed it to extract rents from users). See the discussion in Canada Business Corporations Act \& Commentary (2006/2007 ed.)(LexisNexis Butterworths) at 17-21. Alberta has recently arranged for that form, installing the possibility of competition. Sec the Business Corporations Amendment Act. 2005, S.A. 2005 , cc. 8,40 .

24 It may be observed tangentially that there is jurisdiction shopping on the part of personal wealth interests and Manitoba appetars to catcr to that constituency in creating an estatc-friendly environment.

: Parmership Act. S.M. 1965. c. 59, s. 63.

: See, for example, the undated obstrvations of S. Paul Mantini \& Simon P. Crawford, Bennett Jones LLP. "Property Development: Corporate/Real Fstate." online: Intemet Archive: Wayback Machine <http://wcb.archive.org/web/20051217063057/http://www.lexpert.ca/500/rd.php?area=P5>:

Manitoba limited partnerships are an attractive alternative to linited partnerships formed in other provinces for a number of reasons, the main one being that it appears that the limited partners can exercise a greater degree of control over the partnership and still retain limited liability status.... [Under the Manitoba legislation] additional factors must be established betore the limited partner loses its limited liability status. The limited partner will only be liable for all debts of the partnership to persons with whom it deals on behalf of the limited partnership who do not know that it is a limited parner. leurthermore, this liability extends only to liabilities incurred by the partnership to that person until it first acquires actual knowsedge that it is dealing with a limited partner. Accordingly. the courts will look not only to the actions of the limited partner, but also to the knowledge of the third party. In addition, given the legislative policy, there is room in Manitoba for the argument that, as long as the third party has notice that it is dealing with a limited partner, liability is limited regardless of whether the limited partner exercises control.

$\therefore \quad$ Consider, for example, their use as liability barriers in income fund arrangements.

s. Uniform Limited Parmership Act 2001. NCCUSL. 
control (project risk) without the usual discipline of general liability. The commentary to the uniform legislation, it must be noted, does not credibly justify that fundamental alteration of the conventional limited partnership structure. ${ }^{29}$ Nevertheless, we now have the possibility that local or foreign actors will create an American limited partnership to carry on business in Canada, and its new liability configuration apparently will be recognized in some provinces. $^{30}$ In Ontario, the law of the jurisdiction under which an extraprovincial limited partnership is organized is deemed to govern the limited liability of its limited partners." Accordingly, the limited partners of an extraprovincial American limited partnership will enjoy a substantial immunity advantage over the limited partners of an Ontario limited partnership, even where both limited partnerships conduct their business exclusively in Ontario. That potential circumvention of express Ontario domestic public policy is inexplicable. Presumably it was not the intention of the Ontario legislature to disadvantage its own limited partnerships relative to those created in other jurisdictions (either by foreigners or Ontario residents). Nor, presumably, did it intend to expose its population to the unregulated risk projection of fully immunized limited partners. That, however, is precisely what it has accomplished with its mechanical recognition.

A third instance of differential liability exposure arises with the business trust structure. The conventional position in Canada is that beneficiaries of a business trust may be liable as principals if they exercise control powers over the trustees or the business." Recently, various interest groups in Canada cooperated in an attempt to legislatively extinguish the control liability of beneficiaries in certain types of business trusts. Their efforts, however, appear only to have confirmed the conventional liability. ${ }^{33}$ That being the case, it is nevertheless still possible to circumvent the conventional Canadian liability policy for business trusts if other jurisdictions grant greater liability protection to beneficiaries. There are such jurisdictions. Delaware, for example, now gives beneficiaries the same limited

Sec Flannigan, stipra note 19 at 263-64.

Failure to register, depending on the particular legal form and jurisdiction. may or may not expose participants to general open liability. For limited partnerships. like corporations, the consequence is usually an inability to commence an action. See, e.g. Ontario's Limited Partmerships Act. R.S.O. 1990, c. L.16, ss. 27-28. In the ease of limited liability partnerships, on the other hand, the partners may have the open liability of general partners. See the British Columbia Pormership Act, R.S.B.C. 1996, c. 348, s. I14. See also Batemon v. Service. stupra note 7.

Limiled 'artmerships Act, ihid. s. 27(2). Sec the comparable provision in the Saskatchewan Parmership Acr. K.S.S. 1978, c. P-3, s. 75.2(1)/Sask. PA]. In British Columbia, s. 80(3) of the Parmership Act, ibid., states that "A limited partnership [formed outside British Columbia] has rights and privileges the same as but no greater than, and is subject to the same duties, restrictions, penaltics and liabilities as are imposed on, a [local] limited partnership." The provision may have been intended to address the limiled liability of limited partners. It instead appears to cloud the issue with its references to limited partnerships rather than to limiled partners. See also s. 52(5) of the Alberta Parmership Act, R.S. $\wedge$. 2000. P-3 [Alta. PA].

Tridem Holdings Lid. v. Damand Imesiments Lid. (1988). 64 O.R. (2d) 65 (C.A.): Adlanced Glazing

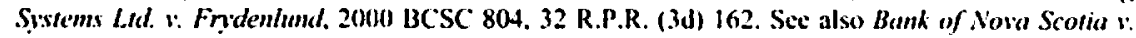
Thiburli. 2004 SCC 29, [2004] I S.C.R. 758.

Some of the statules appear to address only indemnification. A part from that, the conventional position is contirmed by the phrase "as a beneficiary." Sec Flannigan, supres note 19 at 284-85. Subsequently a working group of the (ivil law section of the Uniform Law Conterence of Canada (ULCC) has produced a problematic (and contlicled) neport that, infer alia, recommends a full "liability shield." See The Unifinm Income Trusts Act: Closing the Gup Beween Thadisional Trust Lan' and Curren Governance Expectations (August 2006), online: ULCC <www.ulcc.ca/en/porm2/Uniform_Inconse Trusts_Act_Report_En.pdf $>$. 
liability as sharcholders. ${ }^{3+}$ That liability rule has also been included in the model business trust statute now being drafted by the American uniform law commissioners. ${ }^{35}$ Accordingly, assuming the foreign law will be recognized,$^{36}$ it will be possible to create an American business trust to carry on business in Canada that will have a very different liability configuration for beneficiaries. Here again, the local population will be exposed to the risk projection of actors who do nol bear the consequences of their actions.

A fourth instance of diflerential liability is found in limited liability partnerships. ${ }^{37}$ Different jurisdictions have produced liability consequences that vary in significant respects. ${ }^{36}$ Alberta, for example, immunizes only partners who did not cause the loss or did not supervise the person causing the loss ${ }^{39}$ Saskatchewan offers a wider immunity in that it does not impose liability for a supervisory involvement. ${ }^{40}$ Accordingly, the liability policy of Alberta may be circumvented by organizing a limited liability partnership in Saskatchewan and then registering it as an extraprovincial limited liability partnership in Alberta. In this instance. however, Alberta did seek to address the possibility of a liability differential. After stating that the limited liability of partners in extraprovincial limited liability partnerships is determined by the law of origin, the statute provides that an Alberta partner "does not have any greater protection against individual liability in respect of that partner's practice in Alberta than a partner in an Alberta LLP would have under this Part." That appears to represent an attempt, comparable to that of California, to assert local liability policy. It is problematic, however, in its restriction to "Alberta" partners. Because risk flows (permeates) through forms and across political boundaries, the involvement of non-Alberta partners, with their greater immunity, raises the overall risk associated with the partnership

Del. Code Ann. lit. 12. $\$ \$ 3801-3862$ (2001).

Uniform Staturery Entity Trust Acl (2007 draft). NCCUSL.

The default position is not clear. Consider /J'mphill :. Orloff. 277 U.S. 537 (1928): Mclaren : Dawes

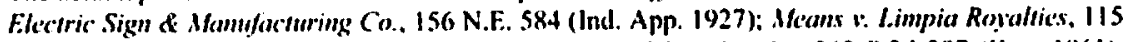
S.W.2d 468 (Tex. Cis. App. 1938); Fergusom v. United Royalty (io., 363 P.2d 397 (Kan. 1961): Greenspm v. Lindhey, 330 N.1:2d 79 (N.Y. 1975). See W.E.N., "The Real Lstate Investment Trust in Mullistate Activity" (1962) 48 Va. L. Rev. 1125 ; Julius A. Shafran, "Limited Liability of Sharclolders in Real Estate Investment Trusts and the Conflict of Laws" (1962) 50 Cal. L. Rev. 696. See also \$298 of the Restatement, supra note 4.

For the history of the development of the limiled liability partnership in the United States and Canada. see Flannigan, supra nole 19 at 267-71.

There is a rough bifurcation between jurisdictions with a "full shicld" against liability and these with a "partial shield." For a description of the difference (but not the justification), sec Alison Oxtoby, "Understanding and Work ing With L.imited L.jability Partnerships." Continuing Legal Education Society of British Columbia (17 November 2006). See also Christine M. P'rzybysz, "Shielded I3eyond Stalle Limits: Ixamining Contlict of Law Issues in Limited Liability Partnerships" (2003) 54 Case W. Res. L. Rev. 605.

Sask. PA, supra note 31, P-3. s. 80.

Alta. PA, supra note 31, s. 1(44(2). See also the similar provision in the B.C. Parmership Act, supra note 30. s. 125. Query the different wording for British Columbia limited partnerships, stupra note 31. 
wherever it operates. ${ }^{.2}$ That increased risk is inconsistent with the liability policy applied to Alberta limited liability partnerships. ${ }^{43}$

A fifth example that illustrates the potential for circumventing liability rules through foreign form selection comes from the non-profit corporation legislation of Saskatchewan. ${ }^{4}$ The statute was recently amended to give immunity to non-profit directors for negligence (including gross negligence) and wilful acts. ${ }^{\text {ts }}$ The policy foundation for that immunity, however, is incoherent. ${ }^{\text {th }}$ The immunity is a patently unsound absolution of director incompetence. Nevertheless, the legislation gives non-profit groups in other jurisdictions the option to incorporate in Saskatchewan and then carry on their activities in their own jurisdictions with an immunity for their directors that is not available even to directors of business corporations. Presumably that option will be exercised frequently once the extent of the immunity becomes widely appreciated, unless non-profit groups are sufficiently ethical (or embarrassed) to adopt an unjustified immunity that operates largely at the expense of their own employees and clients. Other jurisdictions need to consider the potential risk effects on their populations of Saskatchewan's non-profit liability policy and contemplate what they might do to address attempts to circumvent their local liability rules through Saskatchewan incorporation.

These few examples of liability differentials indicate that the blanket recognition of the liability characteristics of foreign legal forms allows sophisticated actors to circumvent local public policy. We have seen that some jurisdictions (California, Alberta, British Columbia) have in certain respects appreciated the potential for circumvention through foreign form selection and have attempted to assert their own liability policy, at least for some legal forms. Why, it may be asked, has that not been the response generally? Why have other jurisdictions uncritically recognized the legal incidents granted by the originating jurisdiction?

\section{THE INTERESTS INVOIVE.D}

Consider the consequences of circumvention. First, the actual operations of the foreign forms will raise the risk of loss for local residents. What justification is there for that increased risk? There is no social benefit in liability protection per se given that liabilities

Exacerbating the effect already present in limited liability partmerships. See Hannigan, suprea note 19 at 268-71. Consider the different wording of s. 54(3) of the New l3runswick Parmership dct, R.S.N.B. 1973, c. P-4.

d3 Consider also the de facto internal liability differential for limiled liability partnerships in British Columbia. The lirst several Canadian jurisdictions to adopt this form restricted its use to professions. British Columbia, however, recently chose to make the structure available to all. The difference is that the professions generally have mandatory insurance cover. That partially dampens the increased risk associated with lormal immunity. Under the British Columbia regime, there is no insurance requirement for non-professionals. The result is that the liability policy of Britislı Columbia essentially produces two levels of risk for one legal lorm. Sec also the regime propessed lor Prinee Edward Island in Limifed Liability Parmership Legistation Discussion Paper (23 Septenber 2005), P. E.I. Office of the Altomey General.

4N Non-profil Corporations ACt, 1995, S.S. 1995, c. N-4.2.

45 Non-profil Corporations Amendment Act. 2003, S.S. 2003, c. 33, s. 112.1.

ts Robert Flannigan. "Tort Immunity For Nonprofit Volunteers" (2005) 84 Can. Bar Rev. I. 
reflect accepted wrongs or failures of duty. ${ }^{77}$ Liability for the adverse consequences of risk projection is fundamental public policy. We are responsible for our actions. Specific dispensations from that norm require, in one form or another, the consent of the community. That consent requirement is bypassed by the perfunctory recognition of immunities fashioned for the forms of other jurisdictions. Second, these liability differences are not visible. There is no requirement for foreign forms to publicize their foreign character (other than registering) or give notice of their different liability configurations. That raises a question of the responsibility of the government of the local jurisdiction. It permitted the liability diflerential and yet does nothing to correct the probable assumption within the population that the foreign liability configuration mirrors the local one. Third, the formal adoption of the greater liability protection of the foreign form undermines local liability policy. If the reduced liability exposure is acceptable for foreign forms, particularly where the foreign form has been established by local actors, why is it not acceptable for local forms? Local policy is also directly undermined in that ongoing sovereignty over liability exposure is surrendered to foreign jurisdictions that can and will amend their liability configurations in the future without regard to the policy choices of other jurisdictions. Ultimately the reality is that the blanket recognition of foreign liability rules promotes covert preferential treatment for foreign forms at the expense of the local population.

There are several factors that might explain the mechanical acceptance of the liability attributes of foreign forms. The first possibility is that there is an information deficit regarding liability differentials between jurisdictions (that is, there is an assumption of common liability configurations). That likely would be true of the general population in every jurisdiction and undoubtedly accounts for the fact that there is no discernible public engagement on the matter. It is a far less probable explanation for the individuals responsible for promoting and drafting the relevant legislation. That suggests there are pragmatic interests at stake and that the law is what it is because it serves those interests.

Following on that, a second possible factor is the interests of the users of these foreign forms, the local and foreign commercial and non-profit classes. They have a general interest in reducing their liability exposure. They have an incentive to wholly or partially externalize risk consequences to their creditors and communities. They absorb the full value of immunity and bear only a portion of its cost. In practice, because these default immunitics can be altered by contract, the benefit is primarily realized on the backs of involtomary creditors. That has been the historical perversion of limitations of liability. ${ }^{48}$ Their primary adverse impact is on those who have no opportunity to escape their operation ex ante.

A third possibility is that liability differentials are compatible with the interests of legal advisors, who in various private and public capacities tend to have considerable influence

s. We seem to be at an adolescent stage where the justification for immunity, at least for those pursuing the immunily, is the bare fact of liability. Ploas for limitations of liability tend to be predicated on the assertion that liability is increasing and that negative ineentives are thereby produced. Most of the content of that claim is demonstrably nonsensical. For the corporate context, where that sort of analysis is often deployed, see Robert Flannigan. "The Personal Tort Liability of Directors" (2002) 81 Can. Bar Rev. 247. For the non-profit context, sec Flannigan, ibid.

A* Flannigan, supra note 19 at 287-90. 
on liability questions. ${ }^{49}$ To lawyers, legal forms of any kind are product or stock in trade, often created or recognized by legislatures at the behest of the profession. It serves the interests of lawyers for there to be a range of alternative products that are ostensibly complex (i.e., not easily provided by other potential suppliers) and that differ either in marginal or fundamental ways. Lawyers sell these products to their clients for various ends, including reducing the risk of liability. More generally, of course, lawyers sell advice about liability exposure. It is in their interest for liability assignments to be uncertain, or substitutable. Further, in the case of the non-profit liability differential, lawyers will have a particular personal interest, as they (or their partners) regularly voluntecr as directors of non-profits for career and client development reasons. Additionally, the lawyers of multi-jurisdiction law firms have a direct personal interest in exploiting liability differentials between limited liability partnership regimes.

A fourth observation is that governments have their own pragmatic incentives to accept foreign law. In some cases it may be that jurisdictions are "played" by interest groups, but the play is usually premised on real or imagined state benefits, such as gaining or not losing market share. ${ }^{50}$ One commoniy asserted benefit for local jurisdictions is the general economic gain (job creation, tax revenue) ostensibly associated with the development of a supportive or "friendly" business environment. Allowing the liability contiguration of the jurisdiction of origin to prevail amounts to a legal subsidy from the local jurisdiction in aid of that objective. It will be appreciated, however, that this subsidy is paid for with the losses unwittingly endured by the local population. That part of the calculation typically remains unquantified or unappreciated. Another supposed incentive is that a blanket recognition of foreign law avoids the costs of having to initially or periodically review all liability differentials across all jurisdictions represented by foreign registrations. The way to address that negative incentive, however, is to adopt the approach some states and provinces have employed of declaring that foreign forms will not receive preferential treatment. That will shift the need to investigate the liability differential to the foreign bodies intending to pursuc undertakings within the local jurisdiction. It will also, as a practical matter, give enforcement options to private parties who suffer loss and who, unlike the state, have a strong stake in enforcement. Another possible motive for the local jurisdiction may be a concern that other jurisdictions might react negatively to any actions taken to assert local policy. Retaliation seems unlikely, however, for the obvious reason that most other jurisdictions (those not exploiting the market for foreign forms) will necessarily appreciate the importance of local policy for local activity. They will not want to diminish, by association, their own authority. Moreover, escalation could be mutual, and mutually destructive. A last possibility is that policy makers in local jurisdictions may simply coldly calculate whether the eslimated social and political costs of liability differentials (which they may regard as modest and largely invisible) exceed the anticipated benefits. To the extent they have done so to date, they apparently have concluded that there is little likelihood their populations will penalize them. partnerships was substantial, and probably determinative. See Flannigan, ibid.

Consider, for example, the privale and provincial manoeuvering with respect to beneficiary liability in income trusts. See Flannigan, ibid. at 277.84. 
A fifth consideration is that there is no organized opposition to these liability differentials. The main interested parties seem content. Even users of local forms likely will not have a sufficient incentive to challenge the law as it stands. They may appreciate having the option to access that law themselves should liability exposure become a substantial concern for them. Possibly they also sense that there is little interest within the commercial class to pursue the matter and that, consequently, there would be few willing to share the costs of seeking reform. They might also be concerned that any new state costs of investigating foreign liability laws would be directly passed on to them through business taxes. As well, they might be uncomfortable with having the state inquire more deeply into liability immunities and their supposed justifications, for that might not turn out well for them domestically if those justifications are found lacking. On the other hand, instead of seeking regulation of foreign liability configurations, local actors may utilize the foreign policy artifacts as political fodder to attempt to lever comparable liability treatment from the local jurisdiction. Lastly, in the case of the general public, even if fully informed, there is likely little prospect of political agitation. It is primarily tort victims who have a pressing personal stake, and they do not self-identify and organize. As has long been the case, the interests of tort victims are ignored because they are not at the table to object when formal loss externalization is arranged for the benefit of others.

These various considerations suggest that the perfunctory or mechanical recognition of the liability configurations of foreign forms will be with us for the foreseeable future. There are significant interests that benefit from that approach, and little organized opposition. Possibly only catastrophic losses to local residents will inspire a reworking of the current position. Perhaps then we might see a move towards equating the liability configurations of local and foreign firms within each jurisdiction. That solution would fairly balance local and foreign liability policies for local activity and purge the instrumental use of foreign forms for backdoor liability circumvention.

\section{Conclusion}

There is no necessary virtue in the blanket recognition of the law of foreign forms. In the particular case of liability differentials, it is an unguarded channel for the acquisition of elite immunities. It amounts to an abdication of local policy and a blunt attack on the local population. States are under no obligation, as a matter of comity or any other rationale, to allow form selection to defeat their liability policies for activities within their boundaries. Their role is precisely the opposite - to control the exposure of their populations to the effects of insulated risk projection. Yet there are reasons to believe that the incentives are othervise for the interested classes, and that there is little will even to explore the matter. That is regrettable. The recent proliferation of legal forms, and the diversity of their liability configurations, has expanded the potential negative consequences of form recognition. If it were not so before, such recognition now approaches state neglect of both fair enterprise and public safety. 